\title{
How Integration Policies have Discovered Religion: German, French and British Politics within the Scope of a Comparative Institutional Analysis
}

\author{
Christine Brunn
}

This article focuses on developments of integration policies in Germany, France, and Britain in the 2000s and aims to examine the increasing attention governments draw to religion. In this decade, all three nation states developed new integration strategies that purposefully try to involve religion and faith groups. Faith communities were supposed to make a significant contribution in promoting integration and community cohesion. Are these political strategies a form of instrumentalist use of religion for political purposes or are they more likely a kind of recognition of religion? Further, the article aims at exploring how the respective integration policy varies, along with particular institutional arrangements in different European countries. For this propose the paper conducts a comparison between Germany, France, and Britain.

A Weberian institutional analysis is conducted combined with a qualitative content analysis of 48 government or government ordered documents. The results of this research indicate that the way in which governments cooperate with faith communities differs considerably in the three countries and is strongly connected to national institutional arrangements.

Christine Brunn received her Dr. rer. pol. in Sociology at the University of Heidelberg in 2011. Her research has focused on integration policy making with particular regard to minority religion. Given her interest in E-Learning, she is currently working as a trainee at the Institut für Lerndienstleistungen (ILD) of Lübeck University of Applied Science (FHL).

\section{Introduction}

During the 2000s particularly Germany, Britain, and France increasingly identified minority religions as a link to implement integration strategies. With the increasing interest in Muslims, but also other minority faith groups, as platforms or mediums for integration measures, religion and religious lifestyles of migrants raised the attention of state agencies in all three cases. Religious affiliation of migrants was no longer perceived only as a barrier to integration or as a source of social conflict but as a serious factor in migrants' self-conception and a means to offer contact points for integration, social cohesion, and dialogue. 
Given the highly different institutional settings in terms of religious governance and migrants integration policy regimes this apparently similar turn to religion in the three countries is noteworthy: Germany is usually classified as a country with a selective cooperation model between churches or faith communities and the state. The religious education in public schools as well as the existence of theological faculties at universities applies to all those churches and faith groups that have contracted with the state. The confrontation with religious plurality and religious minorities seems to be a challenge for German law system (Lepsius 2006, p. 330). In Britain, the Anglican Church is involved in political procedures through a couple of measures. Direct public subsidies are not given. However, the British school system, e.g., allows all major faith groups to contribute to religious education, albeit Christianity has a predominant position in the daily act of collective worship and many state-funded schools are run by religious organizations. In France the influence of religion in the public sphere is limited due to the dominant principle of separation between state and religion. Direct state subsidies for faith organizations are not possible. However, there is state funding for many private schools with denominational orientation, for ministers of religion in public hospitals and in the army, and moderate fiscal advantages for religious associations are available (Nielsen et al. 2009, p. 131). The three countries also represent different integration policy regimes: France with its strictly republican philosophy, Britain with a liberal (multi-)cultural pluralism and Germany with constitutionally guaranteed principles of equal opportunities, but also with a culturalist political rhetoric.

Against that background, the article deals with two research questions: Can the political turn to religion be interpreted rather as a form of instrumentalist use of religion for political purposes or as a kind of recognition of religion? Does the religious turn vary, along with particular institutional arrangements? Following a brief discussion of findings from the literature the article points out two main hypotheses that are theoretically based on a Weberian research program. Before describing the process and results of the qualitative analysis of 48 documents, relevant institutional arrangements both with regard to religious governance and to migrant integration are outlined. The analysis shows that the way in which governments cooperate with faith communities differs considerably in the three countries and is strongly connected to national institutional arrangements.

In this article the term institution is used as a theoretical concept to explain the relationship between action orientations and (opportunity) structures. Institutions can thus be understood as codes or instructions that put values into practice ("Werteverwirklichungsanleitungen", Stachura 2009, p. 14). Hence, institution is not used as equivalent to the term organization. Instead, the meaning of an institution is related to an established order or practice in terms of a Weberian institutional analysis. One of Weber's probably most cited formulations can be found in his sociology of religion: "It is interests (material and ideal), and not ideas which have directly governed the actions of human beings. But the 
'worldviews' that have been created by ideas have very often, like switches, decided the lines on which the dynamic of interests has propelled behaviour" (Weber / Whimster, 2004, p. 69). Albeit Weber has not used the term institution in this context, there is much evidence to understand the term switches equivalent to institutions (Schluchter 2008, p. 58). An institutional analysis postulates that actor and structure determine and constitute each other and that institutions mediate between both. This article proposes as an analogy to a Weberian triad ("Dreiklang", Schluchter 2009, p. 18) of ideas, institutions, and interests to take into account (1) relevant ideas (e.g., religious freedom), (2) their embeddedness in institutional arrangements (e.g., religious regulations, church-state relations, legislation relevant to integration), and (3) the action orientations of actors driven by ideal or material interests.

\subsection{Integration Policies and the Turn to Religion - Findings from the Literature}

Several British authors focused on the recent advancement of minority religion in relation to the British community cohesion policy. Robert Furbey et al. (2006, p. 50) investigated how faith organisations contribute to social capital that enables them to "build bridges and links with others in civil society". Furbey (2008, p. 123) also noted critically that the overall tone in current policy documents referring to the positive social impact of faith is 'instrumental'. Drawing from in-depth qualitative research Dinham and Lowndes (2008) have found that from the perspective of national policy makers faith groups act as a resource for civil engagement and renewal. The authors describe this perspective as being instrumentalist, because faith is only considered in its usefulness for social issues in secular contexts and not as a good-in-itself (Dinham / Lowndes 2008, p. 14).

Tezcan examined the increasing interest of governments in Islam in various European nation states. Referring to Foucault's argument on 'gouvernmentalité' he states that Islam has been governmentalised as a resource to promote integration and secure social order (Tezcan 2007, p. 71). Schönfeld argued that government aided ways of institutionalizing Islamic theology in Germany for example by providing Imam training aim at producing a conformity between attitudes and life styles of Muslims living in Germany and the liberal-democratic concepts of social order (Schönfeld 2014, p. 419).

The literature on the policies of governing religious plurality and Islam in Europe shows evidence that institutional arrangements with regards to integration philosophies and state-church relations are relevant for current integration policies and state dealing with religion, particularly with Muslim recognition claims (Bader 2007; Fetzer / Soper 2005; Koopmans / Michalowski / Waibel 2012). However, the literature also indicates that these institutional settings are not solely responsible for political strategies and decisions concerning integration issues and religious minorities (Bertossi 2007; Koenig 2005; Laurence 
2012). Other aspects, like electoral change or discursive framing of debates about Islam may have an influence on how politics articulate and perform integration measures (Koomen / Stiphout 2013; Lewicki 2014).

Different to recent research on institutional change caused by religious pluralisation in Europe (Burchardt / Michalowski 2015; Maussen 2015; Reiss 2014; Tatari 2009), the focus of this article is not institutional change but rather institutional influenced action of government agencies. The article draws on a Weberian approach that takes into account not only institutions (and ideas), but also interests that are articulated in government or government ordered policy.

\subsection{Developments of Integration Policies and Religious Governance in the 2000s}

During the 2000s, a connection between integration policies and religious governance can be observed in all three nation states. In Germany, the government policies towards Islam were often narrowly connected with integration policy themes. The German Conference on Islam (DIK) was founded in 2006 to establish a long-term dialogue between state and Muslim representatives with the objective of promoting cooperation and dialogue and fostering the integration of Muslims in Germany (Schäfer / Foroutan 2014). Aside from the DIK, other federal founded projects linked to integration policy's objectives drew attention to Islam (Brettfeld 2007; Halm / Sauer / Schmidt / Stichs 2012), for example a Federal Office of Migration and Refugees (BAMF) funded project named 'Imams for Integration'. The project aimed to train Imams about language and the German way of life: "Imams can promote integration as bridge-builders and facilitators between migrants and the host society", then president of the BAMF, Albert Schmid, has been cited as saying when launching the project (BAMF 2009).

In Britain, faith groups have been identified as encouraging agencies for building community cohesion and fostering security during the 2000s (Dinham / Furbey / Lowndes 2009). The Home Office (HO), and, since 2006, the Department for Communities and Local Government (DCLG) play an important role in setting out and reviewing measures to deliver community cohesion by purposefully involving faith. The concept of community cohesion emerged in 2001 and was developed in order to combat strong segregation tendencies between different ethnic groups in Britain. Following the recommendations articulated in the Cantle-Report the British government conducted various programs to promote better relations and mutual support between the different ethnic and religious groups. Government also emphasised that community cohesion must be "underpinned by a sense of people belonging to Britain and to each other, underpinned by common human rights and shared values" (HO 2004, p. 1). This direction towards emphasizing "Britishness" became stronger after the London tube bombings in July 2005 (Thomas 2007, p. 83). From then onwards the community cohesion concept was strongly combined with anti-terrorism strategies, 
too (HAC 2005; HO 2006). British community cohesion policy also promoted cooperation between the state and faith groups (Furbey 2008, p. 122 f.; DeHanas / O'Toole / Meer 2013, p. 29). Faith and faith organizations had advanced to be important partners for national and local governments mainly by contributing with their potential to deliver social services, to bring together different ethnic and faith groups in local and urban areas, to connect between governments and local people, and to prevent terrorism (Jawad 2012, p. 114). Only the latter was explicitly connected with Muslim communities (DeHanas et al. 2013, p. 29) whilst most of the integration and community cohesion related programs followed a more expanded multi-faith focus.

Considering the French case, there was no similar intense connection between integration policy's objectives and strategies for an advancement of religion in the public realm in the 2000s. Nevertheless, the French government launched a public policy towards Islam (Maussen 2007, p. 146-152), particularly by supporting the establishment of a Muslim representative body. These efforts gave rise to the foundation of a French Muslim Council (CFCM) in 2003. However, this does not mean a procedure of recognition in a legislative way - the legal form of the CFCM is that of an ordinary association. The CFCM was supposed to be the contact point for the national government concerning all questions of Muslim life in France. Moreover, the organisation was supposed to fulfil a representative function for all Muslims in France and to legitimize Islam as part of French Republic. For the same reason, the French government has made efforts to establish Imam training in France (Laurence 2012, p. 186; Tuck / Hussain 2014, p. 7 f.). The final report of the Commission de réflexion sur l'application du principe de laïcité (Stasi Commission), commissioned by then President Jacques Chirac, emphasized the importance of the principle of laïcité for French identity and the rejection of all kind of communitarian drifts.

\subsection{Hypotheses - Between Recognition and an Instrumental Use of Religion}

Two main hypotheses have been formulated. The first hypothesis refers to the increasing attention government integration policies draw to religion: This increasing attention appears to be an appreciation and recognition of religion as a goal in itself or, alternatively, as instrumentalist use of religion of that kind that religion is merely of interest for integration issues or other external objectives. Each variant of the hypotheses is associated either with ideal or with material interests due to a Weberian action theory. However, the relationship between both variants is not an exclusionary; rather both variants can be combined.

The second hypothesis refers to the relationship between the institutional arrangements in Germany, France, and Britain in regard to religion and integration policy: The increasing attention integration policies draw to religion suggests a revaluation of the relation between the institutional arrangements of the three 
nation states in regard to religious regulations and integration policies. Such a revaluation can be described as convergence between the institutional surrounding of the three nation states or, alternatively, as a persistent or even stronger accentuation of national particularities.

\section{Method - a Qualitative Document Analysis}

Both hypotheses provide the basis for developing deductive categories for the content analysis (Mayring 2007). First, the documents have been classified according to sample features, history/background, format, authorship and other formal characteristics. Then the documents have been summarized applying stepby-step techniques of paraphrasing, shortening, transforming, and generalizing. Finally, the paraphrased documents were analyzed along 23 categories (s. appendix), mainly by applying different ways of structuring techniques: structuring according to formal aspects, content and by typifying. In the end, a comprehensive synthesis was conducted for each nation state followed by a comparison between the interim findings for the three cases.

According to a Weberian action and structure theory, the methodological procedure follows two purposes: First, the empirical material must be selected in a way that allows for a reconstruction of meaningful action from government actors. Therefore, a deductive disposed qualitative content analysis of government or government ordered documents has been conducted. To identify relevant ideas and institutions, this method is combined with a description of respective institutional settings. For this propose, I consulted mainly law or law-like rules, judicial regulations and, where appropriate, cultural and societal patterns, approved conflict solving strategies, well-tried styles of politics, routines and "institutional conceptions of order" (March / Olsen 1984, p. 743 f.).

Second, both social action and institutional contexts must be scrutinized in a comparative way. The latter suggests an international comparison. The reason for choosing Germany, Britain, and France is that these nation states usually are considered as having paradigmatically different constitutional, legal, administrative and cultural traditions concerning integration and the incorporation of minorities on the one hand and in regard to the regulation of religious affairs on the other (Fetzer / Soper 2005). However, in the 2000s all three countries intensified efforts to accommodate religious practices and, at the same time, to foster integration.

For the qualitative content analysis, a purposive sample of 48 documents, relevant to the issue of both religion and integration policy and written or commissioned by government departments, agencies or representatives from 2000 to 2009 was collected (s. primary sources). 


\section{Institutional Arrangements}

The Weberian approach requires an assessment of relevant institutional arrangements in the three nation states.

\subsection{Institutional Arrangements with Regard to Regulations on Religious Affairs}

The German legal system allows faith communities to organize under public corporation status (GG Art. 140), a legal form that is connected with considerable privileges and a positive recognition in the public. However, mainly Christian congregations and Jewish communities are organized as public corporations whilst most other faith groups are organized as non-incorporated associations (Towfigh 2006, p. 145). Until now, only single Muslim communities in some German federal states are officially recognized as religious communities (Religionsgemeinschaft) in a constitutional sense. However, formal recognition would be relevant, e.g., for being legally entitled to carry out religious education at public schools (Kästner 2011, p. 163). Although it is partly provided without this legal basis, only recognition can guarantee a religious communities' right to religious education as intended in the German constitution. To achieve recognition, religious communities have to demonstrate that they act in favor of comprehensive performance of religious activities induced by the principles given by a common underlying religious denomination. By contrast, charitable aims are neither a precondition for acquiring the public corporation status nor for recognition as religious community.

In Britain, apart from the organizational structure of the Anglican Church, there is no genuine form of organization for faith groups. Faith groups are usually organized as trusts with a charitable status. They enjoy tax benefits (Heyns / Edge / Viljoen 2002, p. 115, 141-143) and a certain public recognition and are normally well integrated in community-based activities and local structures (Fetzer / Soper 2005, p. 51). The British constellation with decentralized administration structures and recognition of faith groups as important agencies of civil society seems to facilitate the local implementation of religious interests. The Charities Acts from 2006 and 2011, but also former Charities Acts, recognize the advancement of religion as charitable aim and refer to a wide definition of religion. However, it is not automatically assumed that the advancement of religion is in the public interest and in case of doubt this has to be verified (Heyns et al. 2002, p. 154). Obviously, different to the French and German case, faith communities and organizations in Britain are strongly associated with social services and charity aims.

In contrast to the British case, the recognition of charitable aims of religious organizations is incompatible with the French system of strict separation between religion and state. Laïcité is supposed to be a fundamental principle in dealing with religion in the public sphere (Freedman 2004). A status under public law is 
not available for faith groups. With the law of 1905 on the separation of church and state a legal form for faith groups has been created, the association cultuelle, which benefits from tax reduction. However, the access to this form of organization depends on the fulfillment of strict conditions and is grounded on a relatively narrow concept of religion and extensive control by authorities. As association cultuelle, faith groups are not supposed to engage in social services or cultural activities. The degree of self-determination is low. That is why most faith organizations that have not been legally recognized before 1905 are today organized according to the law of 1901 as association culturelle (Nielsen et al. 2009, p. 131; Walter 2006, p. 182).

In Germany, the constitutional right to religious freedom (Article $4 \mathrm{GG}$ ) can only be limited when colliding with other constitutional rights (Lepsius 2006, p. 325). However, religious minorities without church-like organisational structures are potentially disadvantaged in claiming religious rights, as legal recognition requires such structure. In Britain, the anti-discrimination or race relations' legislation introduced in the 1960s by the British Parliament opened the way for minorities to claim for particular rights (Poulter 1997, p. 62 ff.; 1998). With the Human Rights Act (HRA) in 1998 (Edge 2000), and even more, with the stepwise introduction of the aspect 'religion' as a category of discrimination since 2003, the legal situation for faith groups in Britain has improved (McLoughlin 2005). Moreover, the multicultural endorsed political rhetoric reflects recognition and openness to (religious) minorities because of their potential of being a resource for integration and community cohesion. Again, the picture in France is different. The volonté génerale does not provide empowerment for minorities (Amiraux 2007, p. 154). Religious freedom is mainly limited to an individual level and is, according to the law of separation of 1905 , subject to restrictions if the public order may be affected. Therefore, religious freedom is to a much smaller degree enforceable by legal action. Faith communities are restricted in their self-determination and freedom of action due to narrow statutory provisions for associations cultuelles or, if organized as associations culturelles, due to missing tax advantages (Walter 2006, p. 220).

\subsection{Institutional Arrangements with Regard to Integration Policies}

Since the turn of the millennium France, Germany, and Britain adjusted their integration policy and initiated new measures to promote the integration of migrants (Rosenow 2007). All three nation states focused on the migrant's command of language and the introduction of integration contracts, courses or tests. However, different integration philosophies are still relevant. Particularly concepts of state-society relations, citizenship and national identity differ. This has implications for national integration paradigms, too. 
The integration mission of Germany builds on the constitutionally guaranteed principles of equal opportunities and democracy and has to be consistent with the principles of human dignity and personal autonomy of the addressees of programs for integration (Langenfeld 2001, p. 351). The British law system does not provide such a high priority of fundamental rights. Following the introduction of the HRA in 1998 an ongoing and controversial debate about the relation between parliamentary sovereignty on the one hand and the judiciary and European Community law on the other has emerged (Ewing 1999; Gordon 2015). However, compared with France and Germany the legal basis for the British integration mission is to a lesser extent systematized but more orientated towards parliamentary guidelines and therefore more adjustable by policymaking (Poulter 1998, p. 45). Non-discrimination legislation - actually even before 1998 in the context of race relations' legislation (Bleich 2003, p. 67; Favell 2001, p. 95) - has been probably one of the most important provisions for integration policy in Britain. Apart from that, the liberal rules of citizenship and the right for Commonwealth citizens to vote enhance the possibility to realize integration through political participation (Le Lohé 2005). However, the British citizenship status is usually not considered as being a distinctive touchstone for political and hence social integration (Heath et al. 2013, p. 139). In France, by contrast, electoral law does strictly depend on obtaining French citizenship and, according to the high priority of political participation, becoming a French citizen seems to be a precondition for integration. However, there is an ambiguous relationship between the idea of republican universalism with an official blindness towards ethnic and cultural differences and the "unofficial departures" from this idea caused by a social reality that is often strongly affected by unequal opportunities and socioeconomic disparities (Schnapper / Krief / Peignard 2003, p. 16, 28).

With regard to minority rights, the three nation states differ too. From a French point of view, the minority concept is not relevant at all, as it is supposed not to be compatible with the concept of free and equal citizens and the immediate relationship between citizen and state (Bizeul 2004, p. 153). The distance to British 'multiculturalism' is regularly emphasized from a French position (Bertossi 2007, p. 57). Although Britain does not follow a legally consistent multiculturalism, particular ethnic or religious identities are not considered as being an obstacle to social integration but as appreciated characteristic of British civil society. Germany again takes an intermediary role. National minorities are officially recognised but minorities that have immigrated to Germany during the last decades are not. Terms like 'parallel societies', used for parts of the population that are said to live culturally isolated from mainstream society, or 'Leitkultur', describing a favoured predominant national culture (Pautz 2005), indicate a clear dissociation from recognising different cultural backgrounds. While French integration discourse rejects multiculturalist approaches, the German discourse supports the idea of a certain culturally homogenous basis for living together. While German integration discourse appears to overemphasize culture, French integration dis- 
course is characterised by overemphasizing the substantial sovereignty of the people (Bizeul 2004, p. $171 \mathrm{ff}$.). In Britain, by contrast, cultural pluralism is often appreciated by politics both by recognizing cultural particularities and considering discrimination as the main obstacle for integration (Schönwälder 2007, p. 247 f.; Ungern-Sternberg 2007, p. 159).

\section{Analysis}

In this chapter, the document analysis with regard to the first (4.1) and the second hypothesis (4.2.) will be described. Only a few categories of analysis are demonstrated as examples. More details are given in Brunn (2012).

\subsection{Religion and State: Between Dialogue, Cooperation, and National Identity}

In Britain public policy initiatives often operate on a regional and local level and include, among other aspects, issues related to integration, community cohesion, and religion. The final report of the Commission of integration and cohesion for example, recommends "a light touch, local driven set of activities (...) rather than a nationally imposed emphasis on cross-cultural friendship" (CommIC 2007, p. 112). Local governments' strategies tend to effectively involve resident faith communities.

Five main areas of faith communities engagement for integration issues can be identified: (1) Faith groups are supposed to contribute to a multi-religious and multi-cultural society, e. g., by participation in initiatives of interfaith dialogue and cooperation (CommIC 2007, p. 113; DCLG 2007a; 2008a, p. 92 ff.; 2008b, p. 31; 2009, p. 20; Gov 2005, p. 8; HAC 2005, p. 3; HO 2005, p. 47; LGA 2002b, p. 22). Several documents assume that faith organizations may help "to deliver many of the Government policies" (DCLG 2006a, 63; 2007a, 7; 2008b, 34). (2) Faith groups are recognized as social service providers with benefits for community cohesion and civil renewal (CharComm 2008b, p. 24; DCLG 2008b, 34; HO 29.03.2004, p. 1; 2004, p. 17; LGA 2002a, 7; 2002b, p. 21 f.). (3) Faith communities are expected to cooperate with the government in the prevention of terrorism (DCLG 2006a, p. 58; Gov 2005, p. 8, 14). (4) Faith inherent values are assumed to have a positive impact on human relations (CharComm 2008b, p. 19; CommIC 2007, p. 86; DCLG 2007b, p. 89; 2008b, p. 31; LGA 2002a, p. 3, 7; 2002b, p. 21). In the consultation of the DCLG framework "Face to Face and side by side", values like "altruism, respect for others, ethical behavior and community solidarity which underpin good citizenship" (DCLG 2007, p. 7) are mentioned. (5) Finally, it is supposed that faith leadership can be beneficial for the wider society: "Ministers of Religion have an important role to play in helping minority communities to engage with British society, in combating extremism and distortion of religion and 
strengthening community cohesion" (Gov 2005, p. 14). To support this role, foreign ministers of religion are supposed to fulfill pre-entry-requirements concerning language skills and knowledge of the British culture and to obtain postentry qualifications like a "management and community leadership course[s] for Muslim faith leaders" (Gov 2005, p. 14; HOFCU 2005, p. 20 f.).

In Germany, integration policies in the 2000s have increasingly drawn on religion and faith issues, too. Political strategies have allocated Muslim faith groups and its leaders a brokering role between host society and migrants. An institutionalized Islam is expected to support the process of encouraging Muslim organizations and stakeholders to become integration agencies. A regularly mentioned issue is also the state accommodation of Muslim religious needs, e.g., by the establishment of faculties for Islamic Theology. To give an example, within the scope of political strategies to foster integration, two ways of referring to religious communities within governmental integration strategies could be identified: (1) German integration strategies frequently focus on the state mission to ensure religious freedom rights of Muslims and to incorporate Islam (Integrationsbeauftragte 2004, p. 10). This mission is associated with the expectation that by conceding constitutional guaranteed religious rights, integration can be facilitated. "Only the cooperation between state authorities and Muslim representatives contributes to improving the basis for the integration of Muslims" (Integrationsbeauftragte 2005, p. 8 f.). Such a naturalization of Islam, strongly orientated toward constitutional guaranteed religious regulations, is continuously relevant for text passages on political strategies to foster integration. Thus, authorities recommend to establish and facilitate Muslim pastoral care and Muslim funeral traditions (Wiesbaden 2007, 5 f.), to introduce Muslim religious education at schools nationwide (Ukom 'Zuw' 2001, p. 236), to foster the building of religious centres (Marburg 2008, p. 2), the provision of Imam training in Germany (Schäuble/SZ 2006, p. 3) and to establish an official representative body for Islam in Germany (Integrationsbeauftragte 2005, p. $8 \mathrm{f}$.). The supposed relationship between legal accommodations and integration is particularly evident when the commitment to the German legal and value system and Muslims' efforts to integrate are presented as precondition for the right to obtain religious freedom (Schäuble 2007b, p. 2; Schäuble/FAZ 20.05.08, p. 4; Wiesbaden 2007, p. 2; Marburg 2008, p. 2).

(2) Another recommendation is to strengthen the cooperation between state authorities and Muslim organizations and representatives in order to increase mutual confidence between Muslims and state authorities, principally the police, with the aim to facilitate integration but also security (Integrationsbeauftragte 2004, p. 10 f.; Polizei/bpb 2005, p. 2). In a similar way, dialogue between state and faith communities and interfaith dialogue are expected to increase mutual understanding with a positive effect on integration (Koalition 2005, p. 117). Muslim communities are supposed to act as facilitators for integration concerns but also as partners in terms of terror prevention. 
In France, republican and laïque principles are considered as the primary and uncontested basis for social integration and are therefore continuously taught, remembered, and highlighted (Chirac 2003, p. 4; HCI 2000, p. 23; 2007, p. 18; 2009). From the analysed documents, two areas can be distinguished. (1) Within the documents it is frequently recommended to incorporate Islam with the aim to confirm and vitalize laïcité. As one measure, authorities and politicians support the establishment of a democratically legitimized representative organisation for Muslims in France (HCI 2000, p. 68; Jolly 2005, p. 12; Sarkozy 2008b, p. 10) and a national curriculum for Imam training in France (HCI 2000, p. 69 f.; Sarkozy 2007, p. 4). Nicolas Sarkozy identifies the CFCM as "facteur d'intégration et d'apaisement" (Sarkozy 2007, p. 3). Imam training in France is characterized as a major step forward in terms of an Islam in France that is compatible with laïque values (HCI 2000, p. 69 f.; Jolly 2005, p. 31). Sarkozy argues, e.g., those Imams with a lä̈que additional training might be messengers for peace, neighbourly love and for respect towards diversity (Sarkozy 2007, p. 4 f.). Further, the reports of Machelon and of Stasi commission recommend creating more positions for Muslim religious workers in prisons, hospitals, and the army (CommSt 2003, p. 64; Machelon 2006, p. 37 ff., 53 ff., 59 ff.). (2) Commissioners and politicians indicate laïcité as being "l'un des moteurs les plus puissants d'intégration" (Rossinot 2006, p. 6, 46) or as "le levain de l'intégration de tous dans la société" (Combest 2003, p. 18), mediating between the recognition of individual identities and collective commitments (HCI 2007, p. 45; Jolly 2005, p. 32) or as being the essential moment of republican integration (Debré 2003, p. 45; see also Machelon 2006, p. 14) and a conception of collective wellbeing and as a guarantee for living together in a tolerant republic that copes with plurality and diversity (CommSt 2003, p. 7, 36).

\subsection{Three Versions of Connection between Integration Policy and Religious Governance}

As previously described, all three nation states have made efforts to involve faith organizations in integration strategies during the 2000s, albeit in different ways. The analysis of German documents revealed a strong reference to single constitutional rights or to the constitution in general (Grundgesetz). Freedom of religion is frequently mentioned (Schäuble 2007a, 7; 2007b, 1; Schäuble/SZ 2006, p. 2; Schäuble/FAZ2008, p. 4; Wiesbaden 2007, p. 1 ff.; Marburg 2008, p. 2; Ukom 'Zuw' 2001, p. 235), but also church-state order (Integrationsbeauftragte 2005, p. 8 f.; Schäuble 2006, p. 1) and the constitutionally guaranteed right to obtain religious education at public schools.

The reference to legal and constitutional settings is ambivalent: On the one hand, politicians and commissioners state that individuals, namely Muslims, are undoubtedly entitled to particular rights granted by the constitution, on the other hand, several times they connect this eligibility with an appeal on Muslims to 
respect and accept the Grundgesetz (Schäuble/SZ 2006, p. 2; Schäuble/FAZ 2008, p. 4; Süssmuth 2008, p. 6; Ukom 'Zuw' 2001, p. 236). Government representatives demand Muslim associations to organise according to constitutional regulations (Integrationsbeauftragte 2005, p. 8; Schäuble 2006, p. 1), albeit they concede that there is a contrast between the highly institutionalized organisation form of Christian churches and emerging Muslim faith groups that are usually organised as associations without a register of members (Integrationsbeauftragte 2004, p. 9; 2005, p. 7; Schäuble/SZ 2006, p. 1; Schäuble/FAZ 2008, p. 3, 4, 5; Schäuble 2006, p. 2;2007a, p. 5).

With regard to integration policies, the analysed documents frequently acknowledge that the state has to grant constitutional rights like equality of treatment and of opportunities, human dignity and freedom of action, right to selfdetermination and to maintain a particular cultural identity (Bundesregierung 2007, p. 3; CDU/CSU 2007, p. 2, 5, 7; Integrationsbeauftragte 2005, p. 11; Wiesbaden 2007, p. 1; Marburg 2008, p. 2; Süssmuth 2008, p. 5 f.; Ukom 'Zuw' 2001, p. 236). However, the documents also refer to the importance of accepting and maintaining a German value system and the binding force of the German free democratic basic order (CDU/CSU 2007, p. 3; Schäuble 2006, p. 2; Schäuble/FAZ 2008, p. 4; Marburg 2008, p. 2; Ukom 'Zuw' 2001, p. 236). Furthermore politicians and commissioners claim that migrants or Muslims have to agree with a democratic "Leitkultur" (Süssmuth 2008, p. 5), a social contract or prevailing principles and norms (Schäuble/SZ 2006, p. 2), accepted social conventions (Schäuble 2006, p. 2), basic norms and rules (Zukunftskommission NRW 2009), important traditions and cultural normalities in Germany (CDU/CSU 2007, p. 3) and Western norms and value standards (Polizei/bpb 2005, p. 9). Particularly, the former minister of inner affairs, Wolfgang Schäuble, emphasizes the importance of Christian traditions and ethics for Western culture, society and the legal system (Schäuble 2006, p. 2; 2007a, p. 2, 4 f.; 2007b, p. 3). Some documents also demand of Muslims to explicitly concede to prevailing rules and conventions in terms of a quasi-contract between Muslim organisations and authorities (Marburg 2008; Wiesbaden 2007; Schäuble 2007b, p. 2).

French policy documents emphasize the virtue of the republican force for integration by highlighting the notion of citoyenneté (CommSt 2003, p. 15; HCI 2000 , p. 7), the unity and indivisibility of the republic (Chirac 2003, p. 3; CommSt 2003, p. 4; HCI 2000, p. 60; Rossinot 2006, p. 3), the specifics of French history and identity (Debré 2003, p. 28; HCI 2007, p. 14), but also constitutional principles like the freedom of religion and conscience (HCI 2000, p. 5, 56; Jolly 2005, p. 11), the freedom of opinion (CommSt 2003, p. 3; Sarkozy 2008b, p. 203) and equal rights of men and women (Chirac 2003, p. 2; HCI 2000, p. 45, 75; 2009, p. 5). Documents consider Laïcité as important both for protecting individual rights and for sustaining the public order (CommSt 2003, p. 21, 58; HCI 2000, p. 58, 72; HCI 2007 , p. 12; Machelon 2006, p. 14). The principle of laïcité is frequently associated with the state's respect and tolerance for religions (Chirac 2003, p. 6; CommSt 
2003, p. 60; Debré 2003, p. 63; Sarkozy 2008a, p. 2), but also with the appreciation of laïcité as a national symbol and a signpost for the concept of national identity (HCI 2009, p. 63, 79; CommSt 2003, p. 3; Chirac 2003, p. 1). While some documents concede the important role religion may play for identity and socialization processes (HCI 2000, p. 23; Jolly, 2005, p. 34), they reject minority claims, e. g., for separate swimming areas, particular opening hours in swimming halls for women (Debré 2003, p. 44, 78; Machelon 2006, p. 14; Sarkozy 2008b, p. 204) or claims for female hospital staff for Muslim women (Rossinot 2006, p. 24) on the grounds that particular collective identities may disturb the direct integration of individuals (HCI 2000, p. 59 f.).

The analysis of documents for the British case has shown three ways of referring to core principles or legal settings in terms of religious regulations and integration policies. (1) The documents refer frequently to abstract liberal principles like tolerance, respect, fairness, and the appreciation of diversity. At the same time, they regularly mention the importance of shared common values and an inclusive Britishness is regularly mentioned (Blair 2006, p. 4 f.; CCP 2004, p. 13; DCLG 2009, p. 20; Gov 2005, p. 15; HO 2004, p. 6 ff.; 2005a, p. 20, 42; HAC 2005, 44, $50 \mathrm{ff}$; LGA 2002a, 3). (2) There is also a prevalent reference to Acts of Parliament like the Race Relations Acts (HO 2005, p. 24 f., 39, 52; HAC 2005, p. 26 ff.) or the Charity Act (CharComm 2008b, p. 3). (3) Finally, the documents often refer to constitutional rights for individuals like the freedom of religion or of opinion (HAC 2005, p. 59) and emphasize, strongly connected to the race relations policies, the protection against discrimination and hate speech on account of religion (HOFCU 2004, p. 4; 2005, p. 21; HO 2005, p. 39, 52; LGA 2002a, p. 1; HAC 2005, p. 26 ff.).

Commissioners and politicians also frequently state that community cohesion policies are most effective on a local level (CommIC 2007, p. 4; DCLG 2008a, p. 8; HO 2005, p. 43; HAC 2005, p. 60) and that measures must be delivered in accordance with specific local characteristics and based on local knowledge (CommIC 2007, p. 41; CCP 2004; DCLG 2006b, p. 3; 2009, p. 6, 12; HAC 2005, p. 37; HO 2005, p. 43 ff.; LGA 2002a, 2002b). They consider faith groups as important local partners for governments and local authorities in the community cohesion agenda: "Faith communities need to be much more involved in all aspects of social policy and, in particular, in helping communities to understand each other and to assist the statutory agencies to work across faith boundaries" (CCP 2004, p. 20). 


\section{Results}

The following section presents results from the document analysis.

\subsection{Britain: Coherence between Recognition and Instrumentalist Use of Faith Communities}

The results from the analysis of the British documents have shown that an instrumentalist use of religion is not in opposition to the recognition of religion. The motives of government policies to advance religion and faith communities rather appear to be orientated towards utilitarian considerations that are in line with recognizing religion as an important social force. Religion is perceived to be beneficial rather than a risk for the common welfare. Faith groups are therefore encouraged to contribute to society and community cohesion by co-operating in local programs or being a partner in political consultation processes. This liberal conception is supported by the British notion of the state that activates, channels, and supervises civil society activities. The utilitarian considerations with respect to religion is connected with a pragmatically oriented and often locally approved British integration model.

\subsection{Germany: Ambivalence between Recognition and Instrumentalist Use of Faith Communities}

The results for Germany show a distinct picture. Integration policy draws on religion, religious facilities, and faith leaders, in a way that shows an ambivalent relationship between recognition and utilitarian considerations. The German mode of recognition is associated with conceding individual and collective freedom of religion, religious self-fulfillment and independence. The basic constitutional narrative is that the legal subjects qualify immediately for having the rights to religious freedom without being committed to external purposes. Thus, their legal claims formally do not depend on their contribution to community cohesion and social integration. According to legal doctrine, orientation on common wellbeing is - in contrast to the British legal form of charities - usually not considered as a necessary precondition for achieving public law status (Heinig 2003, p. $350 \mathrm{ff}$.$) .$

It follows that the German legal principles related to religious governance do not legitimize an obligation for faith groups to take responsibility for integration matters. The growing interests of many integration policy strategies in - mostly Muslim - faith groups can instead be explained by the public and political perception of Islam and its adherents as having general integration deficits. This perception results from a supposed discrepancy between Muslim and Christian 
occidental culture and is strengthened by the culturalist tendency of the discursive framing of integration in Germany (Kontos 2014). Inspired by islamist threat to security following $9 / 11$, this perception engenders integration measures in which Muslims often come into focus when the German legal and value order or criminal preventive aims are pronounced.

\subsection{France: Neither Recognition nor Instrumentalist Use of Faith Communities}

In France, with a predominant political culture that lacks a concept of a positive influence of religion on community and common good, possibilities for faith groups to become visible in the public realm are more restricted. Moreover, an instrumentalist use of religion for political purposes cannot be detected in such an environment. Faith groups are not considered to be common good actors of society like in Britain, nor are they acknowledged as indispensable fundament for guaranteeing the liberty of the state like in the German case (Böckenförde 1976).

However, religion plays a role in the documents considered, albeit a more negative one. Integration is assumed to be the more successful, the less religious affiliation appears to the public as a problem, and the better the respective religious groups are incorporated in existing legal and political structures. Hence, more than in Germany and Britain, in France public und political acceptance of Islam depends on its ability to prove compatibility with core principles and legal provision of the Republic. At best, faith groups are expected to recognise French republican values and to transmit them. Thereby, laïcité is presented as a genuine part of the national identity. The attempts to form a representative organisation of French Islam reflect the state expectation towards Muslims to prove compatibility with French laïcité and are simultaneously linked with the political desire to better control Islam and to support an increasing independency of migrants from their states of origin. The French reluctance to foster faith groups as integration agencies can also be explained by the French philosophy of integration that requires the immediate integration of the subject in the republic and rejects communitarian tendencies.

\section{Conclusion: The Results in View of a Weberian Institutional Analysis}

In accordance with a Weberian institutional analysis, I assume that the respective political action of institutional bounds 'carrier groups' is influenced by particular institutional settings. On the level of action orientation institutions mediate between the ideal and material interests of actors. Accordingly, the focus in the following section lies on the specific constellations of ideas and interests as they relate to institutional arrangements. 
In the case of Britain, the interests of the political stakeholders considered are channelled by both end- and value-rational means of actions. British institutional arrangements enable a coherent mediation between recognition and an instrumentalist use of religion. Religion is regularly associated with the benefit of faith communities for the common good. This approach is augmented by the British philosophy of integration that appreciates the contribution of cultural and religious groups for community cohesion.

In contrast, government agencies' interests in the German case appear mostly to fluctuate in a non-mediated way between value-rational references to legal and constitutional provisions and an orientation towards end-rational motives. This ambiguity becomes apparent, for example, when faith communities are expected to deliver integration services in exchange for recognizing religious freedom concerns. At the level of action coordination, the institutional arrangements are arranged in such a way that the mediation between recognition and an instrumental use of religion comparable to the British case is not fostered. The German Grundgesetz provides procedures of recognition for faith communities, but these procedures do not depend on the communities' engagement for the common good. The temporary linkage between recognition and an instrumentalist use can, however, be explained by political interests that are driven by values and ideas outside of legislation on religion and belief. On the basis of the German culturalist philosophy of integration, being Muslim is often associated with potential integration deficits. In return, Muslims are expected to demonstrate explicitly their willingness to get integrated into the host society. This specific German constellation of ascriptions and expectations towards Muslims opens a window for a utilitarian interest of politics in religion that does not arise from German legislation on religion or belief.

French legislation on religion and belief and French philosophy of integration does not provide an institutional basis on the level of action coordination neither facilitates instrumentalist use nor recognition of faith groups. Although the respect for religion is ensured under constitutional law and the freedom of worship on an individual level is guaranteed, a legal act to recognize religion is absent. Accordingly, there is no basis of legitimacy to express an interest in religion for political purposes. The institutional prerequisites for integration policy are not conducive to involving faith groups in integration strategies, too. This missing link appears to be the reason why none of the two aspects - neither recognition nor an instrumentalist use of religion - can be proved in French government policies of the 2000s. The strong political support for establishing a Muslim representative body can rather be interpreted as a way to reaffirm republican identity and appears moreover ambiguous due to the intervention by the state and disputes over intern credibility and external representativeness of the CFCM and (Pesch 2008, $156 \mathrm{ff}$.$) .$

Hence, the increasing political attention devoted to religion is less a result of changes in religious governance than a consequence of the universal republican 
way to handle integration and cohesion that purposefully attempts to co-opt and thereby pacify presumed disturbing factors, such as religious leaders or faith organisations.

The research presented in this article explores the integration policies' turn to religion in three European countries during the 2000s. It contributes to the argument that the interests of government actors and the narratives are channelled by particular national institutional arrangements. Further research might clarify if governments from 2010 onwards have shifted away from the turn to religion and how far the reference to long lasting institutional arrangements has been changing.

\section{References}

\section{Primary Sources}

Blair, Tony: Speech on Multiculturalism and Integration (8 Dec 06). London 2006.

Bundesregierung: Antwort der Bundesregierung auf die Große Anfrage vom 29. Juni 2006 "Stand der rechtlichen Gleichstellung des Islam in Deutschland". Berlin 2007.

CDU / CSU: Identität und Weltoffenheit sichern - Integration fordern und fördern. Positionspapier zum Nationalen Integrationsplan. Beschluss der CDU/CSU-Bundestagsfraktion vom 24. April 2007. Berlin 2007.

Charity Commission: Analysis of the law underpinning Public Benefit and the Advancement of Religion. 2008a.

Charity Commission (CharComm): Public Benefit and the Advancement of Religion. Draft supplementary guidance for consultation. 2008b.

Chirac, Jacques: Discours prononcé par M. Jacques Chirac, Président de la République, relatif au respect du principe de laïcité dans la République. 2003.

Commission on Integration and Cohesion (CommIC): Our shared future. 2007.

Commission de réflexion sur l'application du principe de laïcité dans la République (CommSt): Rapport au Président de la République. 2003.

Community Cohesion Panel (CCP): The End of Parallel Lives? The Report of the Community Cohesion Panel. 2004.

DCLG: Improving Opportunity, Strengthening Society. One year on - A progress report on the Government's strategy for race equality and community cohesion. 2006a.

DCLG: Strong and prosperous communities. The Local Government White Paper. 2006b.

DCLG: "Face-to-Face and Side-by-Side": A framework for inter faith dialogue and social action. Consultation. 2007a.

DCLG: Improving Opportunity, Strengthening Society: Two years on - A progress report. $2007 b$.

DCLG: Face to Face and Side by Side. A framework for partnership in our multi faith society. 2008a.

DCLG: The Government's Response to the Commission on Integration and Cohesion. 2008b. 
DCLG: Cohesion Delivery Framework: Overview. 2009.

Debré, Jean-Louis: Rapport fait au nom de la mission d'information sur la question du port des signes religieux a l'école. $\mathrm{N}^{\circ} 1275$ - tome I - 1ère partie. Assemblée nationale. 2003.

Government (Gov): The Government Reply to the sixth report from the Home Affairs Committee Session 2004-05 HC 165 Terrorism and Community Relations. 2005.

Haut Conseil à l'intégration (HCI): L'Islam dans la république. 2000.

Haut Conseil à l'intégration (HCI): Projet de charte de la laïcité dans les services publics. Avis à Monsieur le Premier ministre. 2007.

HCI: Faire connaître les valeurs de la République. Faire connaître, comprendre et respecter les valeurs et symboles de la République et organiser les modalités d'évaluation de leur connaissance. Avis à Monsieur le ministre de l'immigration, de l'intégration, de l'identité nationale et du développement solidaire. 2009.

Home Affairs Committee (HAC): Terrorism and Community Relations. Sixth Report of Session 2004-05. Volume I. Report, together with formal minutes and appendix. Ordered by The House of Commons to be printed 22 March 2005.

Home Office (HO): Faith Communities Matter. Press release (29.03.04). 2004a.

Home Office (HO): Strength in Diversity. Towards a Community Cohesion and Race Equality Strategy. 2004b.

Home Office (HO): Improving Opportunity, Strengthening Society: The Government's strategy to increase race equality and community cohesion. 2005.

Home Office Faith Communities Unit (HOFCU): Working Together: Recommendations of the Steering Group reviewing patterns of engagement between Government and Faith Communities in England. Co-operation between Government and Faith Communities. 2004.

Home Office Faith Communities Unit (HOFCU): "Working Together": Co-operation between Government and Faith Communities. Progress Report. 2005.

Integrationsbeauftragte: Religion - Migration - Integration in Wissenschaft, Politik und Gesellschaft. Begrüßung und Einführung auf der Fachtagung Religion - Migration Integration in Wissenschaft, Politik und Gesellschaft am 22. April 2004 in Berlin.

Integrationsbeauftragte: Islam einbürgern - Auf dem Weg zur Anerkennung muslimischer Vertretungen in Deutschland, in: Beauftragte der Bundesregierung für Migration, Flüchtlinge und Integration (eds.), Islam einbürgern - Auf dem Weg zur Anerkennung muslimischer Vertretungen in Deutschland. Dokumentation der Fachtagung vom 25. April 2005 in Berlin. 2005, p. 6-9.

Jolly, Cécile 2005: Religions et intégration sociale. Commissariat général du plan (eds.). 2005.

Local Government Association (LGA): Faith and Community. 2002a.

Local Government Association (LGA): Guidance on Community Cohesion. 2002b.

Machelon, Jean-Pierre: Les relations des cultes avec les pouvoirs publics. Rapport au Ministre d'État, Ministre de l'intérieur et de l'aménagement du territoire. 2006.

Marburg, Stadt: Gemeinsame Erklärung der Stadt Marburg und Vertretern der in der Universitätsstadt Marburg lebenden Migrantinnen und Migranten und Religionsgemeinschaften zur Förderung der Integration durch Zusammenarbeit. 2008. 
Polizei/bpb: Polizei und Moscheevereine. Ein Leitfaden zur Förderung der Zusammenarbeit. Polizeilichen Kriminalprävention der Länder und des Bundes / Bundeszentrale für politische Bildung (eds.). 2005.

Rossinot, André: La laïcité dans les services publics. Rapport du groupe de travail. 2006.

Sarkozy, Nicolas: Allocution du Président de la République lors de la rupture du jeûne à la Grande Mosquée de Paris. 2007.

Sarkozy, Nicolas: Allocution du Président de la République devant le Conseil Consultatif de Riyad. 2008a.

Sarkozy, Nicolas: Der Staat und die Religionen. Hannover: 2008b.

Schäuble, Wolfgang: Deutsche Islam Konferenz - Perspektiven für eine gemeinsame Zukunft. Regierungserklärung. 2006.

Schäuble, Wolfgang: Gehört Religionspolitik zur europäischen "Staatsräson?" - ihr Nutzen und ihre Gefahren. Rede von Bundesminister Dr. Wolfgang Schäuble bei der Tagung "Der Weg Europas und die öffentliche Aufgabe der Theologien" der Europäischen Gesellschaft für katholische Theologie am 8. März 2007 in Berlin. 2007a.

Schäuble, Wolfgang: Religion und Staat. Eingangsstatement von Bundesminister Dr. Wolfgang Schäuble beim Hanns-Lilje-Forum 2007 am 27. März 2007 in Hannover. 2007b.

Schäuble, Wolfgang / FAZ: "Wir müssen den Muslimen Zeit geben". Bundesinnenminister Schäuble, Interview, FAZ (20.05.2008). 2008.

Schäuble, Wolfgang / SZ: "Der Islam ist Teil Deutschlands". Bundesinnenminister Schäuble, Interview, sueddeutsche.de (25.09.2006). 2006.

Süssmuth, Rita: Speech at the Colloque "Religion et intégration, le débat en France et en Allemagne". Maison Heinrich Heine, en coopération avec l'Ambassade d'Allemagne (5 juin 2008), in: Maison Heinrich Heine (eds.), Actes du Colloque. Paris 2008.

Unabhängige Kommission 'Zuwanderung' (Ukom 'Zuw'): Zuwanderung gestalten, Integration fördern. Bericht der Unabhängigen Kommission 'Zuwanderung'. 2001.

Wiesbaden, Stadt: Vereinbarung zur gemeinsamen Förderung der Integration durch Zusammenarbeit (Integrationsvereinbarung) and press release. 2007.

Zukunftskommission NRW: Nordrhein-Westfalen: Integration und Lebensqualität Wie wir morgen leben werden. Bericht der Arbeitsgruppe 3 der Zukunftskommission NRW, in: Kleinert, Hubert et al. (eds.): Innovation, Beschäftigung, Leben. Berichte an die Zukunftskommission. 2009, p. 92-111.

\section{Secondary Sources}

Amiraux, Velérie: 'Religous Discrimination: Muslims Claiming Equality in the EU?', in: Bertossi, Christophe (eds.): European Anti-Discrimination and the Politics of Citizenship. Britain and France. Houndsmill et al. 2007, p. 143-167.

Bader, V.: 'The Governance of Islam in Europe: The Perils of Modelling', in: Journal of Ethnic and Migration Studies 2007/33 (6), p. 871-886.

BAMF: "Imame für Integration" (Pressemitteilung 0017/2011). Nürnberg 2009.

Bertossi, Christophe: 'French and British models of integration. Public philosophies, policies and state institutions', in: Working Paper 2007/46 (University of Oxford: ESRC Centre on Migration, Policy and Society). Oxford 2007. 
Bizeul, Yves: 'Kulturalistische, republikanische und zivilgesellschaftliche Konzepte für die Integration von Immigranten', in: Bizeul, Yves (ed.): Integration von Migranten. Französische und deutsche Konzepte im Vergleich. Wiesbaden 2004, p. 137-175.

Bleich, Erik: Race Politics in Britain and France: Ideas and Policymaking since the 1960s. Cambridge 2003.

Böckenförde, Ernst-Wolfgang: Staat, Gesellschaft, Freiheit: Studien zur Staatstheorie und zum Verfassungsrecht. Frankfurt am Main 1976.

Bolognani, M. / Statham, P.: 'The changing public face of Muslim associations in Britain: Coming together for common "social” goals?', in: Ethnicities 2013/13 (2), p. 229-249.

Brettfeld, Katrin / Wetzels, Peter: Muslime in Deutschland - Integration, Integrationsbarrieren, Religion sowie Einstellungen zu Demokratie, Rechtsstaat und politisch-religiös motivierter Gewalt (BMI, Texte zur Inneren Sicherheit). Hamburg 2007.

Brubaker, Rogers: Citizenship and Nationhood in France and Germany. Cambridge / London 1994.

Brunn, Christine: Religion im Fokus der Integrationspolitik: Ein Vergleich zwischen Deutschland, Frankreich und dem Vereinigten Königreich. Wiesbaden 2012.

Burchardt, Marian / Michalowski, Ines: 'Islam in Europe: Cross-National Differenes in Accomodation and Explanations', in: Burchardt, Marian / Michalowski, Ines (eds.): After integration: Islam, conviviality and contentious politics in Europe. Wiesbaden 2015, p. 105-127.

DeHanas, Daniel N. / O'Toole, Therese / Meer, Nasar: 'Faith and Muslims in Public Policy', in: Singleton, Daniel (ed.): Faith With its Sleeves Rolled Up. London 2013, p. 19-36.

Dinham, Adrian / Furbey, Robert / Lowndes, Vivien (eds.): Faith in the public realm: controversies, policies and practices. Bristol 2009.

Dinham, A. / Lowndes, V.: 'Religion, Resources, and Representation: Three Narratives of Faith Engagement in British Urban Governance', in: Urban Affairs Review 2008/43 (6), p. 817-845.

Edge, P. W.: 'Religious rights and choice under the European Convention on Human Rights', in: Web JCLI 2000/3.

Ewing, K. D.: 'The Human Rights Act and Parliamentary Democracy', in: Modern Law Review 1999/62 (1), p. 79-99.

Favell, Adrian: Philosophies of integration: immigration and the idea of citizenship in France and Britain (2. ed.). Bastingstoke et al. 2001.

Fetzer, Joel S. / Soper, J. Christopher: Muslims and the state in Britain, France, and Germany. Cambridge, England / New York, N.Y. 2005.

Freedman, J.: 'Secularism as a Barrier to Integration? The French Dilemma', in: International Migration 2004/42 (3), p. 5-27.

Furbey, R.: 'Beyond "social glue"? Faith and community cohesion', in: Flint, John / Robinson, David (eds.): Community cohesion in crisis? New dimensions of diversity and difference. Bristol 2008, p. 119-137.

Furbey, Robert / Dinham, Adam / Farnell, Richard / Finneron, Doreen / Wilkinson, Guy: Faith as social capital. Connecting or dividing? Bristol 2006.

Gordon, Michael: Parliamentary Sovereignty in the UK Constitution: Process, Politics and Democracy. Oxford 2015. 
Halm, Dirk / Sauer, Martina / Schmidt, Jana / Stichs, Antje: Islamisches Gemeindeleben in Deutschland. Im Auftrag der Deutschen Islam Konferenz (BAMF, Forschungsbericht 13). Nürnberg 2012.

Heath, Anthony F. / Fisher, Stephen D. / Rosenblatt, Gemma / Sanders, David / Sobolewska, Maria: The Political Integration of Ethnic Minorities in Britain. Oxford 2013.

Heinig, Hans Michael: Öffentlich-rechtliche Religionsgesellschaften: Studien zur Rechtsstellung der nach Art. 137 Abs. 5 WRV korporierten Religionsgesellschaften in Deutschland und in der Europäischen Union. Berlin 2003.

Heyns, Christof H. / Edge, Peter W. / Viljoen, Frans: Legal Responses to Religious Difference. The Hague 2002.

Jawad, Rana: Religion and Faith-Based Welfare: From Wellbeing to Ways of Being. Bristol 2012.

Kästner, Karl Hermann: Gesammelte Schriften (JusEccl 94). Tübingen 2011.

Koenig, Matthias: 'Politics and religion in European nation-states, institutional varieties and contemporary transformations', in: Giesen, Bernhard / Suber, Daniel (eds.): Religion and Politics. Cultural Perspective. Leiden / Boston 2005, p. 291-315.

Kontos, Maria: 'Restrictive Integration Policies and the Construction of the Migrant as "Unwilling to Integrate": The Case of Germany', in: Anthias, Floya / Pajnik, Mojca (eds.): Contesting Integration, Engendering Migration: Theory and Practice. Houndmills, Basingstoke 2014, p. 125-142.

Koomen, M. / Tillie, J. / van Heelsum, A. / van Stiphout, S.: 'Discursive framing and the reproduction of integration in the public sphere: A comparative analysis of France, the United Kingdom, the Netherlands and Germany', in: Ethnicities 2013, p. 191-208. Koopmans, R. / Michalowski, I. / Waibel, S.: 'Citizenship Rights for Immigrants: National Political Processes and Cross-National Convergence in Western Europe, 1980-2008', in: American Journal of Sociology 2012/117 (4), p. 1202-1245.

Langenfeld, Christine: Integration und kulturelle Identität zugewanderter Minderheiten. Eine Unterscheidung am Beispiel des allgemeinbildenden Schulwesens in der Bundesrepublik Deutschland. Tübingen 2001.

Laurence, Jonathan: The Emancipation of Europe's Muslims: The State's Role in Minority Integration. Princeton 2012.

Le Lohé, Michel: 'Ethnic minority participation and representation in the British electoral system', in: Saggar, Shamit (eds.): Race And British Electoral Politics. London: 2005, p. 74-97.

Lepsius, O.: 'Die Religionsfreiheit als Minderheitenrecht in Deutschland, Frankreich und den USA', in: Leviathan 2006/34(3), p. 321-349.

Lewicki, Aleksandra: Social Justice through Citizenship? The Politics of Muslim Integration in Germany and Great Britain. London 2014.

March, J. G. / Olsen, J. P.: 'The New Institutionalism: Organizational Factors in Political Life', in: American Political Science Review 1984/78 (3), p. 734-749.

Maussen, M.: 'The governance of Islam in Western Europe. A state of the art report', in: IMISCOE Working Paper 2007/16, June.

Maussen, Marcel: 'Institutional Change and the Incorporation of Muslim Populations: Religious Freedoms, Equality and Cultural Diversity', in: Burchardt, Marian / Michalowski, Ines (eds.): After Integration. Wiesbaden: 2015, p. 79-104. 
Mayring, Phillip: Qualitative Inhaltsanalyse. Grundlagen und Techniken (9. ed.). Weinheim / Baselfer 2007.

McLoughlin, Sean: 'The State, New Muslim Leaderships and Islam as a Resource for Public Engagement in Britain', in: Cesari, Jocelyne / McLoughlin, Sean (eds.): European Muslims and the secular state. Farnham et al. 2005, p. 55-69.

Nielsen, Jørgen S. / Akgönül / Alibašić, Ahmet / Maréchal, Brigitte / Moe, Christian: Yearbook of Muslims in Europe. Volume 1. Leiden 2009.

Pautz, Hartwig: 'The politics of identity in Germany: the Leitkultur debate', in: Race\&Class 2005/46 (4), p. 39-52.

Pesch, Andreas: “"Gallikanisierung” oder Gleichbehandlung? Die Integration des Islam und das religionspolitische Erbe in Frankreich', in: Heidenreich, Felix / Merle, JeanChristophe / Vogel, Wolfram (eds.): Staat und Religion in Frankreich und Deutschland. L'Etat et la religion en France et en Allemagne. Berlin 2008, p. 140-157.

Poulter, S.: 'Muslim headscarves in school: contrasting legal approaches in England and France', in: Oxford Journal of Legal Studies 1997/17 (1) p. 43-74.

Poulter, Sebastian: Ethnicity, Law, and Human Rights: The English Experience. Oxford 1998.

Reiss, Wolfram: 'Auswirkungen der religiösen Pluralität auf staatliche Institutionen und die Anstaltsseelsorge', in: Polak, Regina / Reiss, Wolfram (eds.): Religion im Wandel: Transformation religiöser Gemeinschaften in Europa durch Migration - Interdisziplinäre Perspektiven. Göttingen 2014, p. 143-182.

Rosenow, Kerstin: Die Europäisierung der Integrationspolitik. Berlin / Münster 2007.

Schäfer, Korinna / Foroutan, Naika: 'Die Deutsche Islam Konferenz im Rückblick (20062013). Analysen einer politischen Initiative zur Gleichstellung von Islam und Muslimen in Deutschland', in: Rohe, Mathias / Engin, Havva / Khorchide, Mouhanad / Özsoy, Ömer / Schmid, Hansjörg (eds.): Handbuch Christentum und Islam in Deutschland: Erfahrungen, Grundlagen und Perspektiven des Zusammenlebens. Freiburg 2014, p. 717-751.

Schluchter, Wolfgang: 'Interessen, Ideen, Institutionen: Schlüsselbegriffe einer an Max Weber orientierten Soziologie', in: Sigmund, Steffen (eds.): Soziale Konstellation und historische Perspektive: Festschrift für M. Rainer Lepsius. Wiesbaden 2008, p. 57-80.

Schluchter, Wolfgang: Die Entzauberung der Welt: sechs Studien zu Max Weber. Tübingen 2009.

Schnapper, Dominique / Krief, Pascale / Peignard, Emmanuel (2003). 'French Immigration and Integration Policy. A Complex Combination', in: Heckmann, Friedrich / Schnapper, Dominique (eds.): The Integration of Immigrants in European Societies: National Differences and Trends of Convergence. Stuttgart 2003, p. 15-44.

Schönfeld, Anne: 'Regulierung durch Wissensproduktion - Staatliche Versuche einer Institutionalisierung der Ausbildung von Imamen in Deutschland', in: Cavuldak, Ahmet / Hidalgo, Oliver / Hildmann, Phillip V. / Zapf, Holger (eds.): Demokratie und Islam. Wiesbaden 2014, p. 399-424.

Schönwälder, Karin: 'Gesellschaftlicher Zusammenhalt und kulturelle Differenz: Muslime und Debatten über Muslime in Großbritannien', in: Wohlrab-Sahr, Monika / Tezcan, Levent (eds.): Konfliktfeld Islam in Europa. Baden-Baden 2007, p. 241-260. Stachura, Mateusz: 'Einleitung. Der Standort weberianischer Institutionentheorie im Raum konkurrierender Forschungsprogramme: Mehr-Ebenen- und Mehr-Seiten- 
Analyse', in: Stachura, Mateusz / Albert, Gert / Bienfait, Agathe / Sigmund, Steffen (eds.): Der Sinn der Institutionen. Mehr-Ebenen- und Mehr-Seiten-Analyse. Wiesbaden 2009, p. 8-39.

Tatari, E.: 'Theories of the State Accommodation of Islamic Religious Practices in Western Europe', in: Journal of Ethnic and Migration Studies 2009/35 (2), p. 271-288.

Tezcan, Levent: 'Kultur, Gouvernementalität der Religion und der Integrationsdiskurs',

in: Tezcan, Levent / Wohlrab-Sahr, Monika (eds.): Konfliktfeld Islam in Europa. Baden-Baden 2007, p. 51-74.

Thomas, Paul: 'From petrol bombs to performance indicators: the 2001 riots and the emergence of "community cohesion" in the UK', in: Waddington, David P. / Jobard, Fabien / King, Mike (eds.): A Comparative Analysis of Recent French and British Riots. Cullompton, Devon; Portland, OR 2007, p. 81-93.

Towfigh, Emanuel Vahid: Die rechtliche Verfassung von Religionsgemeinschaften. Frankfurt am Main 2006.

Tuck, Henry / Hussain, Dilwar: The Education and Training of Islamic Faith Leaders in Europe: A Comparative Evaluation of Approaches in France and Germany (CrossCountry Evaluation Report; Institute for Strategic Dialogue). London 2014.

von Ungern-Sternberg, Antje: 'Individuelle Religionsfreiheit in Großbritannien und

Frankreich unter dem Einfluss der Europäischen Menschenrechtskonvention', in: Kadelbach, Stefan / Parhisi, Parinas (eds.): Die Freiheit der Religion im europäischen Verfassungsrecht. Baden-Baden 2007, p. 143-159.

Walter, Christian: Religionsverfassungsrecht in vergleichender und internationaler

Perspektive. Tübingen 2006.

Weber, Max: Economy and Society: An Outline of Interpretive Sociology. Berkeley and

Los Angeles / London 1978.

Weber, Max / Whimster, Sam: The Essential Weber: A Reader. London 2004.

\section{Appendix}

\section{Categories for the first hypothesis}

(1a) Integration is ... [definition]

(2a) Integration needs ... [preconditions]

(3a) Integration serves as ... [purpose]

(4a) Integration is accomplished by ... [means]

(5a) Religion is ... [definition]

(6a) Religion needs ... [preconditions]

(7a) Religion serves as ... [purpose]

(8a) Religion supports/hinders the integration of migrants

(9a) Religious organisations/communities are supposed to support integration and community cohesion

(10a) National/regional/local political strategies dealing with religion and religious claims are connected to integration purposes 
(11a) National/regional/local political strategies to foster integration are connected to religious issues

(12a) National/regional/local political strategies aim at strengthening the role of religion in civil society

(13a) National/regional/local political strategies aim at supporting the accomodation of religous rights of less etablished faith communities

(14a) National/regional/local political strategies diealing with religion aim at strengthening security policies and measures

(15a) National/regional/local political strategies to foster integration aim at strengthening security policies and measures

\section{Categories for the second hypotheses}

(1b) National/regional/local political strategies dealing with religion do (not) resort to constitutional dimensions

(2b) National/regional/local political strategies dealing with religion do (not) resort to established church-state relations

(3b) National/regional/local political strategies dealing with religion do (not) resort to statutory regulations for religion and religious minorities

(4b) National/regional/local political strategies to foster integration do (not) resort to constitutional and statutory basis for integration policies

(5b) National/regional/local political strategies to foster integration do (not) resort to national discursive framing of religion

(6b) National/regional/local political strategies to foster integration do (not) resort to minorities rights

(7b) National/regional/local political strategies to foster integration and dealing with religion do (not) resort to other national or supranational strategies

\section{Metacategory}

(1c) Similarities and differences in forstering integration and dealing with religion in France, Germany, and Britain 